\title{
Virtualiteit in Dietrich Bonhoeffer se Sanctorum Communio: Kollektiewe intelligensie as nuwe epistemologie vir die kerk?
}

\begin{tabular}{|c|c|}
\hline \multicolumn{2}{|l|}{$\begin{array}{l}\text { Author: } \\
\text { Deon du Toit }{ }^{1}\end{array}$} \\
\hline \multicolumn{2}{|c|}{$\begin{array}{l}\text { Affiliation: } \\
\text { }{ }^{1} \text { Department of Dogmatics } \\
\text { and Christian Ethics, Faculty } \\
\text { of Theology, University of } \\
\text { Pretoria, South Africa }\end{array}$} \\
\hline \multicolumn{2}{|c|}{$\begin{array}{l}\text { Project leader: J. Buitendag } \\
\text { Project number: } 02402343\end{array}$} \\
\hline \multicolumn{2}{|c|}{$\begin{array}{l}\text { Description: } \\
\text { Dr Deon du Toit is } \\
\text { participating in the research } \\
\text { project, 'Theology and } \\
\text { Nature', directed by Prof. Dr } \\
\text { Johan Buitendag, } \\
\text { Department of Dogmatics } \\
\text { and Christian Ethics, Faculty } \\
\text { of Theology, University of } \\
\text { Pretoria and Dean of the } \\
\text { Faculty of Theology. }\end{array}$} \\
\hline \multicolumn{2}{|c|}{$\begin{array}{l}\text { Corresponding author: } \\
\text { Deon du Toit, } \\
\text { ddt@saol.com }\end{array}$} \\
\hline \multicolumn{2}{|c|}{$\begin{array}{l}\text { Received: } 21 \text { Sept. } 2015 \\
\text { Accepted: } 02 \text { Feb. } 2016 \\
\text { Published: } 05 \text { Aug. } 2016\end{array}$} \\
\hline \multicolumn{2}{|c|}{$\begin{array}{l}\text { How to cite this article: } \\
\text { Du Toit D.J., 2016, 'Virtualiteit } \\
\text { in Dietrich Bonhoeffer se } \\
\text { Sanctorum Communio: } \\
\text { Kollektiewe intelligensie as } \\
\text { nuwe epistemologie vir die } \\
\text { kerk?', HTS Teologiese } \\
\text { Studies/Theological Studies } \\
72(3) \text {, a 3206. http://dx.doi. } \\
\text { org/10.4102/hts.v72i3.3206 }\end{array}$} \\
\hline \multicolumn{2}{|c|}{$\begin{array}{l}\text { Copyright: } \\
\text { ( 2016. The Authors. } \\
\text { Licensee: AOSIS. This work } \\
\text { is licensed under the } \\
\text { Creative Commons } \\
\text { Attribution License. }\end{array}$} \\
\hline \multirow[b]{2}{*}{ 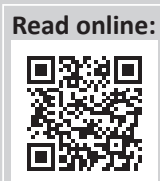 } & \\
\hline & $\begin{array}{l}\text { Scan this QR } \\
\text { code with your } \\
\text { smart phone or } \\
\text { mobile device } \\
\text { to read online. }\end{array}$ \\
\hline
\end{tabular}

\begin{abstract}
Virtuality in Dietrich Bonhoeffers' Sanctorum Communio: Collective intelligence as a new epistemology of the church? Collective intelligence has been indicated from biological, philosophical, anthropological and technological developments. The stygmergy principle serves to explain collective behaviour in nature such as with ants. An earlier form of collective intelligence is found in Leibniz' Monadology. Today, collective intelligence emerges from the anthropological space of knowledge. This article argues that collective intelligence such as Wikipedia is based on a postfoundational epistemology and asks whether this can be seen as a new epistemology for the self and the other. With these insights as hermeneutical interface, Bonhoeffers' ecclesiology in Sanctorum Communio is re-read, and it is argued that Bonhoeffers' church concept as Christus als Gemeinde existierend collectively might serve as a new epistemology for the church.
\end{abstract}

\section{Inleiding}

Snelle tegnologiese vooruitgang, spesifiek innovasie (Soltynski 2006:4-5), oorspoel die samelewing met verandering. Een van die groeperings van hierdie tegnologie is virtuele werklikheid (virtual reality - VR). Deur tegnologiese bemiddeling word moontlikhede aan die mens gebied wat voorheen ondenkbaar was. Vóórheen bekende grense van onder andere tydruimtelikheid word oorskry en bied nie net nuwe vorme van vermaak nie, maar konfronteer 'n mens met 'n werklikheidsbeskouing wat vreemd, fassinerend maar ook bedreigend oorkom (Green 1997; Heim 1993; Nunes 1997:171). Die konsep 'virtualiteit' is nog nie eksplisiet ingeburger in ons werklikheidsverstaan nie, dog het virtualiteit wortels in soveel areas wat raakvlakke met die werklikheidsverstaan het. Die uitwys en ontleding van virtualiteit het in akademiese wetenskappe nog min aandag gekry, en veel minder in die teologie. Hierdie leemtes maak dat daar nie 'n duidelike verstaan van virtualiteit is nie. Die soeke na die verstaan van virtualiteit, nie net as tegnologie nie maar as konsep, bied nog heelwat om te ontgin. Hierdie artikel beskryf virtualiteit vanuit die perspektief van kollektiewe intelligensie en vra of dit ' $n$ nuwe epistemologie vir die werklikheid bied. Vanuit hierdie moontlikheid word 'n nuwe lees van Dietrich Bonhoeffer se Sanctorum Communio ${ }^{1}$ van 1927 deur die hermeneutiese sleutel van kollektiwiteit ontsluit en word gevra of hier 'n nuwe epistemologie vir die kerk te vinde is.

\section{Kollektiewe intelligensie}

Xiaohui Cui (2004) se navorsing in kollektiewe robotika (spesifiek swerm-intelligensie) stel dat kollektiewe intelligensie nie 'n nuwe verskynsel is nie, maar reeds biologies waargeneem is. Dit kom na vore wanneer diere gekoördineerd saamspan om 'n prooi plat te trek en vorm die beginsel dat die kollektief van die dier 'n groter en vinniger prooi kan oorkom as wat 'n individuele dier sou kon. Sosiale diere, soos termiete, bye, voëls en visse, wat individueel 'n laer vlak van intelligensie het, kan deur slegs interaksie 'n intelligente sisteem oplewer wat reaktief teenoor

1.In 1927 verdedig Dietrich Bonhoeffer sy proefskrif, Sanctorum Communio: eine dogmatische Untersuchung zur Soziologie der Kirche suksesvol aan die Universiteit van Berlyn. Dit is in 1930 as'n boek gepubliseer en volgens Green (1999) is 20 tot 25 persent van die inhoud uit hierdie weergawe weggelaat (Green 1999:20). ' $n$ Tweede weergawe het in 1954 gevolg en' $n$ derde en vierde in 1960 en 1969 onderskeidelik. Hulle het die oorspronklike inhoud sowel as aantekeninge van Reinhold Seeberg en Bonhoeffer ingesluit (Green 1999:20). Die eerste Engelse vertaling deur Gregor R. Smith is in 1963 uitgegee, gebaseer op die 1960 weergawe, met as titel The communion of saints: A dogmatic enquiry into the sociology of the church. Hierdie vertaling is in sy geheel in 2011 deur die Internet Archive soos geborg deur die LYRASIS-lede van die Alfred P. Sloan Foundation gratis elektronies beskikbaar gestel deur die boek met ' $n$ aftaster te skandeer en op die Internet te publiseer. Verwysings in hierdie artikel is spesifiek na hierdie Smith-vertaling van 1963 soos toeganklik deur die Internet. In 1985 het Christian Kaiser Verlag, Sanctorum Communio as Band I van die Dietrich Bonhoeffer Werke (DBW) opgeneem. Fortress Press het die Engelse weergawe hiervan in 2009 gepubliseer (DBWE) (kyk na Schlingensiepen 2010:xxiii). Sanctorum Communio in hoofletters verwys in hierdie artikel na Bonhoeffer se publikasie en sanctorum communio in kleinletters verwys na die teologiese begrip vanuit die Apostolicum.

Note: This article is a reworked version of a PhD dissertation entitled 'Virtualiteit in Dietrich Bonhoeffer se Sanctorum Communio', presented in partial fulfilment of the requirements for the degree of Philosophiae Doctorae, completed in 2015 in the Faculty of Theology, University of Pretoria under the supervision of Prof. Dr Johan Buitendag. 
mekaar en aanpasbaar teenoor die omgewing kan optree. 'n Enkele mier kan nie intensioneel die kortste afstand na voedsel bepaal nie, maar ' $n$ kolonie miere vermag dit ondeterministies. Dieselfde meen Cui gebeur ook by mense wat saamwerk vanuit die beginsel dat twee koppe beter is as een (Cui 2004:28). Dit herinner ook aan Prediker 4:9 se 'twee vaar beter as een'. Kollektiwiteit versaak nie die individu nie; die individu bly bestaan as entiteit op sigself, maar is terselfdertyd deel van 'n groter geheel.

Intelligensie is die woord wat algemeen gebruik word om 'n (spesifiek menslike) individu se vermoë om te leer, probleme op te los en aan innerlike en uiterlike omgewings sin te gee, mee te omskryf (vgl. Davis 1998). Szuba (2001) het egter aangetoon dat die dissipline kunsmatige intelligensie (artificial intelligence) sedert ongeveer 1950 veroorsaak het dat intelligensie op enige mens, organisme of sisteem van toepassing kan wees. Cui wys ook op'n verdere ontwikkeling van intelligensie aan die hand van die voorbeeld van 'n rekenaar wat 'n skaakmeester klop. So blyk dit dat intelligensie daaroor gaan om 'n oplossing vir 'n probleem te kan bied. Sou die skaakmeester die rekenaar klop, beteken dit nie noodwendig dat die rekenaar onintelligent is nie, maar bloot dat die rekenaar se kennisbron nie voldoende is nie. Kollektiewe intelligensie gaan dan spesifiek oor die volgende (Cui 2004:24): 'The synergistic ability of a group of agents to produce better solutions to a problem than the sum of the abilities of all agents working individually'.

Buitendag (2013:8) vra die vraag of die kollektivisme van 'n miernes (met verwysing na Eugene Marais ([1925] 2007) se epistemiese waarneming van mierkolonies) meer as net 'n metafoor vir die werklikheidsverstaan is. Dit blyk of Buitendag Marais se siening oor die kollektiewe en deterministiese aard van die mierkolonie-verskynsel steun as hy Marais se begrippe soos 'van buite af bestier', 'besturende mag', 'morele band', 'voorgesê' en 'groepsiel', beklemtoon (vgl. Buitendag 2013:8; Marais [1925] 2007).

Volgens Holland en Melhuish (1999) word hierdie gedrag egter verklaar deur 'n biologiese verskynsel naamlik stigmergie. Stigmergie dui op gemeenskappe met swermintelligensie se indirekte kommunikasiemedium by selforganisering. Dit word bepaal deur vier begrippe: positiewe terugvoer, negatiewe terugvoer, afwykingsversterking en veelvuldige interaksies. Daar is waargeneem dat miere dikwels een pad volg sowel as dat 'n enkele mier afwyk van die pad. Sodoende ontdek die mier dalk nuwe voedsel of selfs 'n korter pad na bestaande voedsel. Gegrond op positiewe of negatiewe terugvoer (byvoorbeeld feromoon-afskeiding of -verdamping) begin ander miere die afwykende mier volg en word die afwyking deur veelvuldige interaksies versterk en bring dit sodoende 'n verandering tot gevolg. So ontstaan 'n kollektiewe kompleksiteit wat daarin slaag om 'n spesifieke taak soos die insameling van voedsel te verrig.

Dit mag dalk voorkom asof Buitendag in stryd is met die stigmergie-beginsel. Stigmergie wys Marais se hipotese oor 'van-buite-af-bestiering' af, maar dit wys nie Buitendag se hipotese oor meer-as-blote-metafoor-vir-werklikheid af nie. In teendeel, dit bied in lyn met Buitendag se argument nog 'n dimensie van werklikheidsverstaan aan. Cui dui dat hierdie beginsels van kollektiwiteit in virtuele kollektiwiteit ingebou word. So bied virtualiteit ook meer as net nuwe woordeskat, maar wel 'n nuwe verstaan van die werklikheid. Aristoteliese mistici soos Al Farabi, Ibn Sina, Abu'l-Barakat al Baghdadi en Maimonides het reeds met hulle opvatting oor die entiteit genaamd Aktiewe Intellek, die fondament vir die verstaan van kollektiewe intelligensie gelê (Aristoteles 2009):

The many, who are not as individuals excellent men, nevertheless can, when they have come together, be better than the few best people, not individually but collectively, just as feasts to which many contribute are better than feasts provided at one person's expense. ... Hence the many are better judges than a single man of music and poetry; for some understand one part, and some another,and among them they understand the whole. (bl. 1281)

Hulle het Aktiewe Intellek beskou as dit wat ware idees oordink en na die mens gereflekteer het om weer te interpreteer en te oordink. Hierdie gedeelde intellek was die skakel tussen God en mens, 'n God wat self-reflekterende denke is, ' $n$ kennende wese en vorm van kennis, 'n ware intellek van waaruit kreatiwiteit voorspruit (Lévy 1999:92). In die Middeleeue was dit spesifiek Leibniz se metafisika, genaamd monadologie en sy simboliese taal wat verdere ontwikkeling in die denke oor kollektiewe intelligensie aandui.

\section{Leibniz se monadologie}

In Leibniz se The monadology van 1666 stel hy sy teorie dat die werklikheid uit verskillende nodes, wat hy monades noem, bestaan. Alle monades is op ' $n$ manier aan mekaar verbind soortgelyk aan ons verstaan van 'n matriks. Die term monade kom van die Griekse woord monas wat monnik en monopolie beteken. Dit het te doen met 'n spesifieke soort eensaamheid of afgesonderheid. Elkeen leef in eensaamheid in isolasie van die ander volgens sy eie lewensvoorkeure. Elke monade bestaan as 'n onafhanklike punt van lewens- en wilskrag, aangespoor om sy eie lewensdoel volgens sy willekeur te behaal. Monades het nie ruimtelike dimensies nie, maar produseer ruimte as byproduk van hulle aktiwiteit. Hulle is nie bewus van 'n buitewêreld nie en het nie ' $n$ breëre visie nie. 'The Monads have no windows, through which anything could come in or go out' (Leibniz 2007:7). Die denkwêreld van die monade is 'n reeks interne voorstellings en verteenwoordigings. Die werklikheid is 'n konstante stroom voorstellings wat voor die sigmeganisme van die monade geplaas word. Dit word op so manier geplaas dat die monade dit bloot sien vir wat dit is. Die monade kan slegs deur hierdie koppelvlak ken. Die monade versamel en bewaar al hierdie kennis wat hy bloot perseptueel en sensories inneem, los van tyd, ruimte en omstandigheid. Al wat werklik bestaan, is diemonade. Die res is bloot persepsieen waarnemings. Nietemin praat Leibniz se monadologie in die meervoud van monades, want daar word ' $\mathrm{n}$ netwerk monades veronderstel. Elke monade vorm een van hierdie waarnemings vir die ander monade. Elk monade bevat die heelal in sigself. Elke mikrokosmos bevat die makrokosmos - mundus concentratis 
(Leibniz 2007:5). In 'n gekonsentreerde werklikheid kan monades mekaar nooit van aangesig tot aangesig ontmoet nie, want hulle 'bestaan' nie vir mekaar nie (hulle is bloot waarnemings vir mekaar). Onderliggend aan die monades is daar ' $n$ Sentrale Oneindige Monade wat soortgelyk aan die sentrale bedryfstelsel van 'n hoofraamrekenaar is. Heim (1993:91) toon aan dat Leibniz ([1710] 2009) in 'n werk, Theodicy, skryf dat die Groot Rekenaar of Groot Rekenkundige (Great Calculator) vrye wil gerespekteer het omdat Hy slegs aan die begin van alles ingemeng het (en van daar af nie weer in die verloop van oorsaak en gevolg ingemeng het nie). So meen Lévy (1999) dat die ekonomie van menslike eienskappe soortgelyk is aan 'n monadologie sonder God (of 'n Groot Rekenaar-entiteit). Niemand besit mag nie. Niemand besit absolute kennis nie. Die enigste berekening, indien enige, is dié van onberekenbare onsekerheid - slegs benaderings (Lévy 1999:83).

\section{Die kennisruimte}

Kollektiewe intelligensie sal, volgens Lévy, uit die antropologiese ruimte van kennis voortspruit. Die kennisruimte sal soos met die opkoms van sy voorgangers alle ander voorafgaande ruimtes omvat en bepaal. Effektiewe en spoedeisende kollektiewe intelligensie sal die sukses en voortuitgang van die mens bepaal. Dit sal gedryf word deur die hoë tempo van die evolusie van kennis, die groot aantal mense wat hierdie nuwe kennis sal moet aanleer en die ontwikkeling van ondersteunende tegnologie (Lévy 1999:141). Hierdie ruimte word bewoon deur verbeeldingryke kollektiewe wat voordurend, dinamies rekonfigureer. Kollektiewe intelligensie skep muterende tale, konstrueer virtuele universe en kuberruimtes waar onbekende vorme van kommunikasie mekaar opsoek. Hierdie ruimte bestaan nog nie outonoom nie. Dit is virtueel en kan terugskouend in alle ruimtes en tye geïdentifiseer word (Lévy 1999:139).

Hierdie ruimte word nie net deur tegnologie ondersteun nie, maar word daardeur bepaal. Lanier (1988:s.p.) meen dat mense met virtualiteit hulle eie werklikheid kan konstrueer so vinnig as wat daaroor gepraat kan word. Só word die wêreld kollektief deur 'n vorm van kommunikasie gevorm (Lanier 1988). Volgens Zhai het hierdie tegnologie ook 'n wesenlike impak op hoe die mens sigself in tyd en ruimte beskou, want deur kommunikasie en tele-teenwoordigheidstegnologie is ons tegelykertyd hier en daar (Zhai 1998:74).

Alhoewel kollektiewe intelligensie as verskynsel lank reeds bestaan, was dit die stigting van die Massachusetts Institute of Technology (MIT) se Sentrum vir Kollektiewe Intelligensie op 13 Oktober 2006 wat akademiese statuur daaraan gegee het. Sou 'n mens Roux en De Beer (2013) se uiteensetting van kollektiewe intelligensie aanvaar, word ingesien hoekom dit so effektief in kennisvermeerdering ingespan word en tot die stigting van akademiese sentrums kan lei:

Nie alleen is ' $n$ groep slimmer as ' $n$ individu nie, maar so kom verskillende benaderings, kriteria, prioriteite en so meer in spel en onder die vergrootglas. Terselfdertyd plaas dit wetenskaplike navorsing weer midde-in die wetenskapsgesprek en word navorsing werklik kennisvermeerdering. (bl. 293)
Tydens die openingsrede van die MIT se Sentrum vir Kollektiewe Intelligensie stel Malone dat kollektiewe intelligensie 'n groep individue behels wat iets kollektiefs doen wat blyk intelligent te wees. Families, maatskappye en lande is almal groepe bestaande uit individue wat blyk intelligent op te tree. Die menslike brein bestaan uit individuele neurone wat kollektief intelligent optree (Malone 2006:1).

Meer onlangse voorbeelde van kollektiewe intelligensie is instansies soos Google, wat algoritmes en gesofistikeerde tegnologie gebruik om antwoorde kollektief te vind deur miljoene webruimtes gelyktydig te deursoek. Wikipedia gebruik minder intensiewe tegnologie maar slaag met vernuftige organisasiebeginsels en motivering om duisende mense van regoor die wêreld te kry om kennisbydraes te lewer en 'n kollektiewe aanlyn-versameling daarvan te skep. Maatskappye maak toenemend en met groot sukses van vooruitskattingsmarkte gebruik waar mense vooruitskattings rakende marktoestande verhandel (Malone 2006:2).

Bogenoemde is bloot karige voorbeelde van hoe tegnologie soos die Internet gebruik kan word om kennis vanaf miljoene mense wat op lukrake maniere aan mekaar verbind is, op voorheen ongekende skaal in te oes. Malone (2006) meen dat dit voordelig sal wees om hierdie verskynsels dieper te ondersoek:

So, it's time to make collective intelligence a topic of serious academic study ... The key question we're using to organize our work is: How can people and computers be connected so that collectively they act more intelligently than any individual, group, or computer has ever done before? (bl. 2)

Volgens Malone het Eric von Hippel van die Sloan School 'n studie gedoen wat toon dat die kollektiewe gebruikers van 'n produk dikwels ' $n$ beter bron vir innovering as 'n maatskappy se eie navorsers is. Om bloot enige iets kollektiefs te doen, beteken nie dat dit waarde het of noodwendig beter sal wees nie. Daar is egter ook diégene wat skepties staan teenoor kollektiwiteit en desentralisering en meen dat niks sonder sentrale beheer suksesvol kan wees nie. Nie een van hierdie twee ekstreme is noodwendig reg nie. Daar is reeds heelwat ondersoeke vanuit die sielkunde, die organisasieteorie, kunsmatige intelligensie, die breinwetenskap en andere velde gedoen. Nuwe tegnologie maak dit nou moontlik om groepe te organiseer op nuwe maniere wat voorheen ongekend was. Dog blyk dit dat mense nog nie weet hoe om voordeel hieruit te put nie (Malone 2006):

We hope we can make a contribution just by helping to frame the questions better and also to contribute to scientific understanding in many different disciplines and help us understand new and better ways to organize businesses, to conduct science, to run governments, and - perhaps most importantly - to help solve the problems we face as society and as planet. (bl. 4)

Kollektiewe intelligensie wat bepaal word deur netwerke van kennisruiling en kennislewering veroorsaak dat kennis die nuwe infrastruktuur geword het (Lévy 1999:2). Soltynski (2006) toon dat organisasies slegs kompeterend sal bly 
indien hulle toepaslike aanleersisteme in plek het (Soltynski 2006:8). Vanuit die beginsel dat veranderende ekonomiese omstandighede ' $n$ antropologiese verandering teweeg bring, toon Lévy dat die verandering in die arbeidsmark ' $n$ ontwikkeling van handvaardighede na kennisvaardighede ondergaan het. Dit het toenemend noodsaakliker geword om mense se intellektuele vermoë op ' $\mathrm{n}$ gereelde basis te beoefen. Maatskappye wat hiervolgens aanpas, sal floreer in die toekoms. Inteendeel dui Lévy aan dat die ekonomie nie langer meer primêr aangedryf sal word deur groot maatskappye wat anonieme arbeid bestuur en beheer nie, maar eerder deur ' $n$ omgewing waar konfrontasie plaasvind tussen interafhanklike vaardigheidsones wat interaktief en wedywerend is. Die vermoë om vinnig intellektuele gemeenskappe te kan vorm en hervorm, sal die beslissende wapen word (Lévy 1999:4-5). Tovey (2008) verwoord dit soos volg:

To understand future democracies, we need to understand past democracies. To understand future legal and administrative systems, we need to understand past administrative systems. ... In each case we need mechanisms to extract what worked, and what didn't, what was missing, and what was available in overabundance. ... This will be a multi-disciplinary effort. (bl. 459)

\section{'n Nuwe epistemologie?}

Sou kollektiewe intelligensie as 'n nuwe epistemologie aanvaarbaar kon wees? Kollektiewe intelligensie gaan oor die verkryging, beskikbaarstelling en uitruil van kennis, maar is nie primêr afhanklik van 'n spesialis (expert) nie. Iemand wat ' $n$ minder ernstige mediese probleem het, kan tevrede gestel word deur antwoorde vanuit 'n kollektiewe gemeenskap in te win. Sulke antwoordesluit waarskynlikhede sowel as onwaarskynlikhede in. Dit versamel die verhale van mense met soortgelyke probleme en word oorweeg vir toepaslikheid al dan nie. Van hierdie menings mag dalk selfs dié van medici wees, maar word nie noodwendig belangriker as anekdotiese menings geag nie. Persoonlike ervarings en kliniese navorsing word onder dieselfde kam geskeer en daar word eerder gesoek na aspekte van kontekstuele assosiasie as navorsingsgebaseerde resultate. Die kennis wat so bekom word, is dus nie noodwendig universeel van aard nie, maar eerder van toepassing op die eie individuele konteks en ervaring. In hierdie konteks speel kulturele en sosiale assosiëring dikwels ' $n$ groot rol. Dit word nie streng objektief beskou nie en daar word eerder na betroubaarheid gesoek.

Dit mag dus blyk dat kollektiewe intelligensie se epistemologie nie voldoen aan vereistes wat stel dat kennis universeel, objektief en altyd geldend moet wees om waar te wees nie. Dit pas nie in by wat in die suiwer wetenskap as die regte metode van omgang met die waarheid beskou word nie. Hierdie artikel argumenteer egter dat hier 'n moontlikheid is vir ' $n$ nuwe epistemologie wat die leemtes van 'n vorige epistemologie aanvul. Hierdie argument word gesterk vanuit die nadenke oor moderniteit se epistemologie en nadenke wat postfoundationalism as 'n nuwe epistemologie in die vooruitsig stel. Wentzel J. Van Huyssteen het die metodiek van die moderniteit onder drie karaktereienskappe gestruktureer. Dit waarteen postfoundationalism argumenteer, naamlik foundationalism, staan vir ' $\mathrm{n}$ epistemologie wat eerstens gebaseer is op ' $n$ benadering wat stel dat kennis van 'n fundamenteel onbetwisbare waarheid afhanklik is. Enige kennis moet teruggelei kan word na sodanige waarheid en daarom word persoonlike oortuiging (basic beliefs) as ongeldig beskou (Van Huyssteen 2006:14). Kennis kan dus bedryf word deur 'n spesialis (individu) wat sy kennis aflei vanaf genoemde onderliggende onbetwisbare waarheid. Tweedens is foundationalism van mening dat kennis universeel moet wees (Van Huyssteen 2006:15). Die kulturele en sosiale ingebedheid van kennis moet vermy word, en kliniese resultate is die enigste aanvaarbare. Dit bring die derde eienskap van foundationalism ter sprake wat objektiwiteit primêr stel as die aanvaarbare manier om met kennis om te gaan (Van Huyssteen 2006:15-17).

Tyson (2008) dui dat epistemologiese foundationalism tot by Descartes teruggaan. Die waarheid was vir Descartes geleë in wat die mens onbetwisbaar weet en kan deur menslike logika of rede of persepsie gedemonstreer word. Alhoewel dit die onderbou van alle wetenskaplike metodiek vorm is dit filosofies feilbaar. Hume het daarop gewys dat hierdie fundamentele solipsisme dus teologies destruktief was aangesien dit tot epistemologiese nihilisme lei. Dit het beteken dat waarheid dus slegs prakties of krities kon wees maar nie metafisies of teologies nie. Kant het probeer om die situasie te red, maar het eintlik net die probleem gekompliseer, want volgens Kant het daar iets soos 'n werklike bestaan, maar dit is onkenbaar. Sowel die modernisme as die postmodernisme is krities teenoor spiritualiteit. Enige poging tot ' $n$ kombinasie van epistemologie en die transendente is dus onhoudbaar vanuit die modernisme en die postmodernisme (Tyson 2008:246-248). Epistemologiese foundationalism het volgens Tyson ' $\mathrm{n}$ foutiewe ontoepistemologie, en pleit daarom vir 'n terugkeer na die Platonisme. Die ontwikkelingslyn van epistemologiese foundationalism loop vir Tyson soos volg: Dit begin by Plato se epistemologie en transendensie. Dan volg 'n Christelike neoPlatonistiese Aristotelianisme soos te vind by Thomas van Aquino en Bonaventure. Hierdie via antiqua was in teenstelling met die via moderna wat met Ockham begin het en deur die Renaissance tot by Descartes geloop het. Dit het met die Verligting in Hume doodgeloop. Tyson meen dat die moderne realisme, positivisme, anti-realisme en postmoderne irrealisme almal deel is van die dieselfde onto-epistemologiese familie waarteen postfoundationalism betoog.

Die drie sake, fundamentele onbetwisbaarheid, algemeengeldendheid en objektiwiteit is nie vir postmoderniteit die allerbelangrikste nie. Van Huyssteen meen dat die moderniteit se eie regstelling teen die allerbelangrikheid van hierdie drie, nonfoundationalism, ook nie voldoende is nie is en bloot wisselterme vir dieselfde saak is (Reeves 2013:133). Waar die moderne met foundationalism gepaard gaan, gaan nonfoundationalism en postmoderniteit hand aan hand. Van Huyssteen stel postfoundationalism in die 
plek van foundationalism voor op grond van 'n positiewe sowel as negatiewe strategie (Reeves 2013:134). Die negatiewe strategie is dat foundationalism die eie beginsels weerspreek omdat dit geen kritiese status aan fundamentele geloofsoortuigings (beliefs) gee nie. Voorstanders van foundationalism beperk enige rasionaliteit as dit by oortuigings kom. Hierteenoor stel postfoundationalism dat daar nie iets soos ' $n$ onbetwyfelbare oortuiging bestaan wat as fondament dien waarop alle ander kennis bou nie. Die postmodernisme het juis uitgewys dat sosiale konteks en tradisie 'n fundamentele vertrekpunt wesenlik beïnvloed. Om te meen dat kennis universeel moet wees, is beperkend vir rasionaliteit en kennis. Sosiale en kulturele konteks is belangrik. Die beweging vanuit foundationalism na nonfoundationalism het ook in teologiese nonfoundationalism na vore gekom. Hieroor wys Van Huyssteen daarop dat die onvoldoenbaarheid van teologiese nonfoundationalism is dat voorstanders daarvan nie die bron van hulle oortuiging verklaar nie. Hulle stel hulleself bo enige kritiek en isoleer hulleself eintlik in die proses en help nie mee om die teologie ' $n$ waardige gespreksgenoot vir die wetenskap te maak nie. Die postmodernisme verleen eintlik regverdiging aan hier isolerende groeperings (Van Huyssteen 1999:78).

Van Huyssteen se positiewe strategie is dat postfoundationalism die beste aspekte van sowel foundationalism as nonfoundationalism moet insluit. Postfoundationalism erken dat 'n sekere rasionaliteit relatief tot 'n persoon en situasie is, selfs al is die intensie daarvan om universeel te wees. Hy bepleit ' $n$ swak vorm van objektiwiteit, maar stel nie in die plek van objektiwiteit dat persoonlike oortuiging nader aan die waarheid is as ' $n$ ander nie. Hy meen die derde, naamlik postfoundationalism, kan hierdie leemtes vul (Reeves 2013:132).

Kollektiewe intelligensie dra die eienskappe van postfoundationalism. Rodrígues betoog dat Wikipedia 'n postfoundationalist epistemologie huldig (Rodrígues 2007:178). Hy noem dit 'n gespreksepistemologie (conversational epistemology) en meen dat dit in pas is met Van Huyssteen se transversal rationality. Wikipedia wil die leemtes wat 'n foundationalist ensiklopedie soos Encyclopaedia Britannica laat, gebruik as geleentheid om 'n kennisbron op grond van 'n nuwe epistemologie beskikbaar te stel (Rodrígues 2007:173). Dit wil die epistemiese voorrang van die natuurwetenskap, wat op grond van onkritiese aannames en deur onkontekstuele wetenskaplike analise kennis aflei, opponeer: 'Wikipedia has evolved organically into a cross-cultural, cross-contextual, interdisciplinary conversation that can help liberate epistemology - especially theological epistemology - from the stranglehold of Enlightenment foundationalism' (Rodrígues 2007:175).

Geen dissipline kan daarop aanspraak maak dat dit die enigste manier is om kennis te bekom nie. Van Huyssteen stel dat 'n mens moet wegbeweeg van 'n situasie waar jy altyd die kundige (expert) moet raadpleeg en dat 'n mens eerder betroubaarheid en oordeelkundigheid voorop moet stel: '... rationality indeed requires other people, and not just any people, but people with the skills needed to exercise judgement and deliberate on particular issues within specific contexts' (Van Huyssteen 1999:147).
Van Huyssteen wys ook daarop dat die postmodernisme en nonfoundationalism nou verwant is. Nonfoundationalism verwerp die idee dat daar vaste fondamente van kennis kan wees en meen dat kennis eerder ' $n$ web van oortuigings is wat deur sosiale ligging gevorm word. Aansprake op die waarheid is afhanklik van 'n konteks. Daar is geen maatstaf om tussen waarhede en rasionaliteite te onderskei nie. Dit is 'n soort relativisme wat die postmodernisme se gefragmenteerdheid en die pluralistiese aard van die menslike rede onderlê (Reeves 2013:133).

'n Bykomende waarde van virtualiteit is daarom dat dit aan die hand van kollektiewe intelligensie ' $n$ nuwe epistemologie vir die werklikheid aanbied. Hierdie epistemologie kan vir alle wetenskappe, insluitend die teologie, tot groot voordeel wees. Dit is ' $n$ bevrydende epistemologie en ontsluit die vaardighede van mense tot voordeel van die gemeenskap. Mense se kontekstuele en sosiale vorming word ook weer erken en help mee tot indentiteitsvinding in die 21ste-eeuse samelewing. Verder help dit ook mee tot die gelowige se verstaan van kerk en geloofsgemeenskap. Die volgende afdeling neem hierdie diskoers verder.

\section{Die ekklesiologiese konteks van Bonhoeffer se Sanctorum Communio}

As Lutherse teoloog is Bonhoeffer daarin geskool dat Luther die kerk as Personsgemeinschaft en nie as instituut nie beskou het. Nagmaal was vir Luther nie net die sakramentele nie, maar ook die sosiale. Die bemiddeling van Christus wat met die nagmaal gevier word, is terselfdertyd ook 'de sociale oervorm van menselijk samenleven onder het beslag van Christus' (De Lange 1993). Luther stel ook in die Groot Catechismus van 1529 die Duitse woord, Gemeinde, as wisselterm vir ekklesia en communio bekend. Vir Luther was die kerk 'n gemeenskap van mense, met en vir mekaar. Volgens De Lange het hierdie karakter van die Lutherse Kerk in Duitsland egter gaandeweg weens die institusionalisering van die kerk getaan en bepleit Bonhoeffer juis weer 'n terugkeer na hierdie gemeenskapskarakter van Luther se ekklesiologie. Die kerklike afgrensing teenoor die Rooms Katolieke Kerk (RKK) het ingehou dat die reformatoriese ekklesiologie die klem op die institusionele karakter van die kerk gelê het. Dit kom duidelik na vore by Calvyn. Volgens Calvyn is die kerk primêr 'n uiterlike hulpmiddel vir die geloofsontwikkeling van die individuele gelowige. Al noem Calvyn, in navolging van Cyprianus en Augustinus, die kerk die moeder van alle vromes, piorum omnium mater (Calvyn $1845: I V, 1,1)$, en al erken hy dat daar vertroosting in die term gemeenskap is, is die kerk vir hom eerder van instrumentele as intrinsieke waarde. Omdat die kerk vir Calvyn eerder 'n middel tot die heilsdoel is, meen De Lange dat Calvyn geen sosiale doel op sigself in die kerk gesien het nie. Kerkbanke was vir Calvyn skoolbanke en daarom gaan die kerk oor die les en nie die verhouding met die leerders nie. 'n Duidelike voorbeeld hiervan is Calvyn se beskouing van die sanctorum communio soos in die Apostolicum vervat. 
In Calvyn se Institusie IV het hy die term communio sanctorum van die Apostoliese Geloofsbelydenis uiteengesit as die versameling van diegene wat uitverkies is vir die roeping om God se naam te verheerlik. Hierdie gemeenskap is vir Calvyn te vinde in die Goddelik uitverkose lede van die liggaam waarvan Christus die hoof is. Dit is vir Calvyn die enige en ware kerk, volk van God, tydens hierdie lewe sowel as tydens 'n toekomstige lewe. Die eenheid van hierdie liggaam is gemeenskap. Dit gaan oor die deelname aan 'n hemelse toewyding, uitgesonder onder die heerskappy van God. Hierdie gemeenskap van die gelowiges deel onderling in al die seëninge van die vaderskap van God en die hoofskap van Christus.Slegs God ken die samestelling van die uitverkiesing. Elke lid moet die kennis van die uitverkiesing oorstyg en die verantwoordelikheid van deelname aan Christus se enige kerk opneem. In Institusie IV I stel hy dat, tensy ons met alle ander lede onder Christus die Hoof verenig is, ons geen hoop op enige toekomstige erfenis het nie. Die term communio was vir Calvyn meer as ' $n$ sosiale instelling. Dit is vir hom 'n groepering van individue wat bewus is van hulle onderlinge gemeenskap, wat in goddelike seëninge deel en wat in gedurige kommunikasie met mekaar verkeer. Elkeen moet sigself toespits op die eenheid van die liggaam. Die ware sanctus kom tot sy reg in die gemeenskap en word deur God self gevorm en gevoed. In die woord gemeenskap vind Calvyn troos en hoop. Die enkeling se lewe van pyn en worsteling is deel van 'n groter en dieper gemeenskap wat in en deur God lewe. So het Calvyn tussen die sigbare en die ware of onsigbare kerk onderskei. Die sigbare kerk is die vergestalting van die ware kerk. God se ware kinders in die sigbare kerk deel in die gemeenskap van die onsigbare kerk. Die belydenis van geloof, ' $n$ voorbeeldige lewe en deelname aan die sakramente is die teken van die ware gemeenskap. Vir Calvyn het die tydlike en sigbare in die onsigbare en ontydruimtelike opgegaan. Die gemeenskap van die heiliges word deur openbare aanbidding versterk. So word God verheerlik en word ' $n$ voorbeeldige lewe aangemoedig. Wanneer God as 'onse Vader' aangespreek word, word die band van eenheid beklemtoon en kan seëninge gedeel word. Van hieruit kring wyer humanitêre aksie uit. Die doop is dit waardeur die uitverkorenes deel kry aan die gemeenskap. Dit is die sterkste band wat die eenheid met Christus bevestig. Die lede word deur die nagmaal versterk en verkwik in die geloof. Die eenheid van die onsigbare gemeenskap roep lede tot ' $n$ heilige en rein lewe, mededeelsaamheid, vrede en samewerking. Die verwonding van een is die verwonding van die hoof, Christus. Almal moet toegewyd wees aan mekaar en aan God.

De Lange meen hierdie geïnstitusionaliseerde kerkbegrip, minimalisme, was juis waarteen Bonhoeffer in Sanctorum Communio argumenteer het. Hy het dit as 'n fundamentele fout van die protestantse kerkleer beskryf. Die politieke situasie in Duitsland na 1918, meen De Lange, het 'n groot invloed op die vorming van Bonhoeffer se denke gehad. Die Grondwet van die Weimar-republiek het 'n sosiologiese lugleegte in die samelewing gelaat. Individualisering in die samelewing was toenemend aan die orde van die dag en het die kenmerk gedra van 'elkeen vir sigself'.
Aan die een kant was daar die liberalisme wat vanuit 'n minimumkerk-beginsel argumenteer het en aan die ander kant was daar die konserwatisme wat vanuit die maksimumkerk-beginsel geargumenteer het (Ballard 1974:269). Die liberalisme was gekant teen die institusionalisering van die kerk en het ' $n$ vrye en informele gemeenskap, sonder enige ideologiese terughouding van gelowiges, bepleit. Klem is gelê op sterk persoonlike bande in die gemeenskap. Volgens Ballard het die liberale tradisie openbaring tot blote godsdiens gereduseer. Al wat die mens moet doen om sy of haar doel te bereik, is om die einddoel van sy of haar natuurlike geskiedenis uit te leef. Die Duitse Jeugbeweging, wat die natuur en landelike lewe idealiseer het, was die draer van hierdie beskouing. In reaksie hierop het die konserwatiewe mening, die volkskerk, sterk steun ontvang. Die kerk moes 'n aktiewe rol, veral polities, in die samelewing inneem. Die kerk moes 'n kontra-kultuur vorm wat 'n konserwatiewe magsblok in die staat opneem. Dit is as die maksimumkerk-beginsel beskryf. Tesame hiermee het daar ' $n$ herlewing van die later-Lutherse kerkbegrip van afgrensing teen die RKK (wat verkeerdelik as institusionalisering deur die voorstanders van hierdie herlewing geïnterpreteer is) plaasgevind. Dit is in hierdie kerklike landskap waarin die jong Karl Barth se dialektiese teologie ingespeel het. Hy distansieer hom van die liberale individualisme sonder om die konserwatisme te omhels. Hy herstel openbaring weer tot ' $n$ vrye wilshandeling van God, maar, meen Ballard, dit het gekom teen'n prys, naamlik dat die openbaring van die werklikheid van die empiriese kerk losgemaak is (Ballard 1974:269). Barth het in sy Romeine-kommentaar die ekklesiologie gedekonstrueer. Elke sigbare vorm van die kerk staan onder die oordeel van God. Hy plaas in sy kerkbeskouing sterk klem op die ekklesiologiese teologie. Die skeiding tussen die sigbare en onsigbare kerk word met die volgende beginsel verklaar: Die eindige kan nie die oneindige verstaan nie (finitum non capax infinitum). So meen De Lange is die sigbare gestalte van die kerk van teologiese prominensie ontneem.

Bonhoeffer het met Sanctorum Communio die teenoorgestelde hiervan bepleit. Hy vereenselwig nie die onsigbaarheid van die kerk met die verborgenheid van God nie. Die verborgenheid van God, absconditus dei, word verstaan vanuit die feit dat God in die onverwagse of teenoorstaande te werk gaan, sub contrario in mundo. Die sigbare van die kerk, in hierdie geval die sosiale gemeenskap, kan daarom juis iets van God se handeling omsluit. So word die empiries-waarneembare kerk, anders as by Barth, weer teologies relevant. Volgens Marty (1962) het Bonhoeffer soos volg gedink:

Barth and the Confession Church have encouraged us to entrench ourselves behind the 'faith of the Church', and evade the honest question, what is our real and personal belief? ... Much the same applies to the suggestion of the dialectical theologians that we have no control over our faith, and so it is impossible for us to say what we do believe. There may be a place for such considerations, but they do not release us from the duty of being honest with ourselves. (bl. 35) 
Bonhoeffer se Sanctorum Communio maak dus van die sosiale gestalte van die kerk weer 'n allerbelangrike agendapunt. Hy ondersoek in watter mate die kerk draer van die openbaring is. Om dit te kan bereik, moes hy die sosiologiese en die teologiese metodiek met mekaar versoen. Dit word volgens Ballard vervat in die formule van Christus als Gemeinde existierend (Ballard 1974:270; vgl. ook Bonhoeffer 1963:203). Volgens De Lange is Sanctorum Communio die eerste belangrike poging in die protestantse tradisie om die sosialiteit van die kerk opnuut teologies te verwoord. Die kerk as gemeenskap was wel 'n algemene term van sy tyd, maar Bonhoeffer slaag daarin om in die spektrum van konserwatisme, liberalisme, sowel as neo-Lutherse kerkbeskouings iets nuuts te sê en terselfdertyd die onkritiese individualisering van die samelewing uit te wys. Vir De Lange is dit egter opmerklik dat Bonhoeffer individualisme afwys, maar wel nog steeds teologiese waarde aan die individu verleen. Die rede waarom Bonhoeffer daarin slaag, is omdat hy argumenteer vanuit wat God oorspronklik met die kerk en die gemeenskap bedoel het. Sy vertrekpunt is juis nie gemeenskapsentiment nie. Sodoende is hy suksesvol daarmee om die empiriese gestalte van die kerk weer prominensie te gee. Die kerk is vir hom nie net ' $n$ abstrakte teologie nie, maar die alledaagse realiteit van die Duitse volkskerk (De Lange 1993).

Bonhoeffer ontwikkel sodoende 'n kerkbegrip waar die individualiteit van die onderlinge gelowige erken word. Bonhoeffer se ekklesiologie is 'n Christo-ekklesiologie. Die nuwe dimensie wat Bonhoeffer vanuit sy werklikheidsverstaan, naamlik Christuswirklichkeit, bring, is dat nie net die kerk nie maar ook die gemeenskap van die kerk (sanctorum) se oorsprong in Christus is. So argumenteer Bonhoeffer vir die kerk as die empiries waarneembare kerk. Dit is ' $n$ gemeenskap wat naas ander gemeenskappe in die wêreld bestaan. Dit is egter nie wat bepaal dat die kerk kerk is nie. Gemeenskap bepaal kerk, maar gemeenskap gekwalifiseer as sanctorum communio.

\section{Die Christelike persoon}

Vir Bonhoeffer hou die konsepte persoon, gemeenskap en God met mekaar verband. Om te verstaan wat Bonhoeffer as kollektiewe persoon beskou, is dit nodig om eers sy konsep van die Christelike persoon te verstaan. Roark (s.a.:s.p.) beaam dit ook as hy stel dat die gemeenskap iets reflekteer van die persoon van waaruit dit na vore kom. Bonhoeffer argumenteer sterk vanuit die sondeval. Die Christelike persoon is die mens wat kennis het van goed en kwaad. Die mens het deur die sondeval aan die een kant die diepste isolasie moontlik ervaar, maar aan die ander kant ook die wydste moontlike assosiasie met die mensdom beleef. Adam het die mensdom in sonde gedompel en die verbintenis tussen God en mens verbreek (Bonhoeffer 1963:71). Hierdie verbintenis word slegs deur Christus herstel. Die konsep 'persoon' kan dus nie los van God en spesifiek los van Christus gesien word nie. Mens leer iets van God ken deur iets van die Christelike persoon te ken (Bonhoeffer 1963: 40-41). Ballard dui aan dat God vir Bonhoeffer in verhouding tot die mens tree as die 'Ander'. Hy skep die skepsels deur aan hulle vryheid te gee en dit voort te sit deur sy werklikheid as genade te bevestig (Ballard 1974:271). God is die God-virmy. Dit is die aard van sy voorsienigheid. God bewaar sy skepping en laat nie toe dat dit net verdwyn nie. Hy is toegewyd daartoe en heers deur sy volgehoue teenwoordigheid oor die mens. Dit word bevestig deur die werklikheid van God-as-mens, Jesus Christus - God gee Homself as die bevestiging hiervan. Die werklikheid bestaan uit die self, God en die naaste (Ballard 1974:271). Deur die handeling van die skepsel kom die self tot die besef van die ander en tot die besef van sigself. 'Only by his action does the other become the Thou for me, from which my I arises' (Ballard 1974:271). Elke menslike $u$ is 'n beeld van die goddelike U. Die aard van die $\mathrm{u}$ is die gestalte waardeur God geken word. Aan die hand hiervan stel Ballard dit soos volg: 'Who? is the question of the transcendence'. Volgens hom is dit die enigste legitieme Christologiese vraag. Geloof gaan juis ook oor die ander. Gemeenskap en geloof kan nie losgemaak word van mekaar nie.

God beskou nie die mens as 'n geïsoleerde persoon nie, maar as ' $n$ wese in verhouding met ander, wat sigself voortdurend in die gemeenskap as 'n ek vind (Bonhoeffer 1963:35). Hierdie ek staan voor ander en ook voor God as 'n U. In die ek-U verhouding word die Christelike persoon ' $\mathrm{n}$ persoon op sigself, nie wanneer God die persoon konfronteer as 'n U nie, maar wanneer Hy by hom of haar ingang vind as 'n Ek. Die individu behoort dus in wese en in absoluutheid saam met die ander, volgens die wil van God, self al is dit ' $n$ feit, of selfs vanweë die feit, dat die een heeltemal apart van die ander is (Bonhoeffer 1963:37). Roark (s.a.:s.p.) dui ook aan dat Bonhoeffer die Christelike persoon in nie-statiese terme definieer. Die konsep 'persoon' fluktueer en bestaan slegs waar die mens moreel verantwoordelik is, passievol in ' $n$ morele struweling is en gekonfronteer word deur sigself te oorweldig.

So, argumenteer Bonhoeffer, verskyn 'n nuwe eenheid anders as ' $n$ absolute en relatiewe eenheid - naamlik die kollektiewe persoon. Hierdie nuwe eenheid mak egter nie dat wederkerigheid in gemeenskap ophou bestaan nie. Die individuele persone bly nog steeds los van mekaar bestaan (Bonhoeffer 1963:69). Binne die struktuur van persone beklee die kollektiewe persoon dieselfde rol as enige ander individuele persoon. Eenheid en gemeenskap sluit mekaar nie uit nie, is ook nie identies nie, maar benodig mekaar wel (Bonhoeffer 1963:69). Roark (s.a.:s.p.) meen dat hierdie gemeenskap gekonstitueer word deur wil en begeerte en nie deur 'n formele ooreenkoms nie. 'n Gemeenskap is waar die lewe geleef word.

\section{Die kollektiewe persoon}

So, meen Bonhoeffer, het God 'n doel met die kerk ook. Dit is die gemeenskap wat vanuit God, tot God, bestaan. Die gemeenskap leef vanuit die wil en genade van God. Dit kan slegs deur die kollektiewe persoon bereik word, wat as individue hoor, bekeer en glo. Volgens Roark (s.a.:s.p.) maak 
Bonhoeffer die punt dat die Bybel nie oorspronklike sonde ken nie, maar wel en slegs die universaliteit van sonde. Die sonde van die individu en die universaliteit van sonde moet as ' $n$ eenheid beskou word. Die kollektiewe skuld van 'n gemeenskap is daarom iets anders as die skuld van 'n sosiale verskynsel in 'n gemeenskap. Dit is die mense wat hulle moet bekeer. Dit gaan egter nie oor die hoeveelheid mense of oor die kerk in geheel wat hulle bekeer nie, maar oor die kollektiewe persoon wat kollektief skuld bely en om vergifnis pleit. Die individuele persoon moet hierdie rol van die kollektiewe persoon op sigself neem en kollektief wil om saam te bely. Dit is waarop die kollektiewe etiese gemeenskap gebou word. Die kollektiewe persoon het 'n hart. Die kollektiewe persoon se hart klop daar waar die individu sigself as sowel deel van die individu as deel van die mensdom wat voor God se heerskappy buig, beskou. Dit is die setel van morele eenheid - dit het een gewete. Sodoende is elke mens Adam. Die mensheid van Adam bestaan uit individue, maar is een as mensdom en sondig in geheel saam. Die mens is aan die een kant individu en aan die ander kant kollektief Adam. Hierdie dualiteit van die aard van die mens kan slegs tot niet gemaak word met ' $n$ eenheid in die nuwe mensdom in Christus - die kerk (Bonhoeffer 1963:84-85).

In wese praat Sanctorum Communio oor twee kollektiewe persone, naamlik die persone van die eerste en die tweede Adam. Die eerste Adam is die mens ná die sondeval en die tweede Adam is Christus. Die tweede Adam is Christus wat as Christus as die kerk bestaan. Christus word beskryf in hierdie formule, met verwysing na Paulus se 'Christus is die kerk' (Bonhoeffer 1963:84-85). Om in Christus te wees, is dieselfde as om in die kerk te wees (Bonhoeffer 1963:100). Christus dra die nuwe lewensbeginsel van die kerk in Homself saam (Bonhoeffer 1963:107). Dit word ook uitgedruk as die Liggaam van Christus (Bonhoeffer 1963:139). So is Christus self ' $n$ kollektiewe persoon, wat kollektief die kerk verteenwoordig en self ook die kerk is.

Dit, meen De Jonge (2012), is 'n hermeneutiese manier van dink. Bonhoeffer se persoonsteologie van openbaring beteken dat God ten volle deur die persoon van Jesus Christus intree in menslikheid. God se wese word so deel van die geskiedenis. God se versoening met die mens is nie net iets wat anderkant die ewigheid bestaan en bloot in die geskiedenis van die mens manifesteer nie, maar dit bestaan slegs in die geskiedenis van die mens - dis is openbaring in die geskiedenis in die persoon van Jesus Christus. Bonhoeffer meen daar word deur Jesus Christus 'n eenheid tussen God en mens bewerkstellig (De Jonge 2012:9).

\section{Wederkerigheid in verhoudings}

Die kerk is God se nuwe doel vir die mens. Sy wil is altyd op werklike historiese mense gerig en het daarom sy beginpunt in die geskiedenis. Op ' $n$ gegewe punt in die geskiedenis het dit sigbaar en verstaanbaar geword. Aangesien die oorspronklike gemeenskap van die mensdom, waardeur God spreek en optree, verdorwe geraak het, moet God deur die Woord Homself openbaar en 'n nuwe skepping, die mensdom, na vore bring. Net soos wat die kerk sy ontstaan in Christus het, net so word dit ook in Hom vervul. Hy is die hoeksteen, die fondament en die volheid van die gebou - dit is sy liggaam. Om in die versoening van Christus te glo, beteken dat God nie net bloot versoen ter wille van versoening nie, maar dat God se versoeningsdaad die ganse mensdom in die oog het en daarom skep Hy die nuwe Adam. As die kerk, met sy oorsprong in Christus, sigself verder opbou, moet hierdie wil van God gedurig opnuut gerealiseer word (Bonhoeffer 1963:104).

Volgens Bonhoeffer het die Nuwe Testament twee konsepte van die kerk - Jerusalem s'n en Paulus s'n. Die eerste, die Joods-Christelike, is die basis van die Rooms-Katolieke beskouing. Die laasgenoemde, die nie-Joods-Christelike, is die basis vir die Lutherse beskouing. In die Jerusalembeskouing was daar van die begin af ' $n$ duidelike hiërargie: 'n goddelik-bepaalde orde, 'n goddelike kerkwet en 'n kerk as 'n instituut waarin individue opgeneem is. 'n Duidelik gedefinieerde groep, die apostels, dit is Jakobus en die twaalf, het ' $n$ standhoudende goddelike voorafbepaaldheid gehad wat hulle as die leiers aangetoon het.

Paulus het hierdie beskouing van die kerk op grond van sy verstaan van die evangelie oorkom. $\dot{\varepsilon} \kappa \kappa \lambda \eta \sigma i \alpha$ is die Septuagint se vertaling van $\frac{e}{e} d h \bar{a}$ en vir Paulus ook van לדזָ, wat ook as


'bymekaarkoms' beteken en verskil nie veel van $\sigma v v \alpha \gamma \omega \gamma \dot{\eta}$ nie. Later het $\sigma v v \alpha \gamma \omega \gamma \dot{\eta}$ die individuele Joodse gemeente

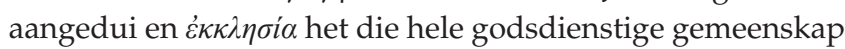

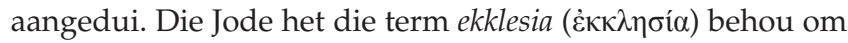
hulleself mee te beskryf. Die opneem van hierdie term deur die Christelike gemeenskap was moontlik omdat dit ook reeds in die Grieks te vinde was, alhoewel meer as ' $n$ politiese term vir 'byeenkoms'. Die Christelike gemeente, ekklesia, word nie deur nasionale of politieke grense beperk nie, dit is universeel. Alhoewel steeds 'n volk, vorm die gemeente met die Heidene en die Jode 'n volgende generasie. Om die Grieke te help om dit te verstaan, praat Paulus van die ekklesia


maar hy gebruik dit ook om die plaaslike gemeenskap aan te dui. Sy redes is nie net linguisties nie, maar ook teologies. Die plaaslike kerk is die konkrete vorm van die geheel van die kerk, maar dit is terselfdertyd die kerk van God. Dit is die vorm waarin die hele kerk op een plek vergestalt word. Met ekklesia verwys Paulus daarom altyd na dít wat God op die aarde gestig het, selfs al verwys hy net na die plaaslike gemeente. Die kerk bestaan deur die werk van Christus sowel as die werk van die Heilige Gees. Die kerk is deur Christus uitverkies, van ewigheid af. Die nuwe mensdom leef in Christus. Dit is die tweede Adam, die nuwe Adam (1 Kor 15:45; Bonhoeffer 1963:98). Die mensdom word deur Hom verlos, want Hy het homself vir die kerk gegee en die oprigting van die kerk beteken die aktualisering van dit wat reeds in Christus bereik is. Christus is die fondament, die hoeksteen van die kerk. Hy is die begin van die nuwe mensdom, die eersgeborene tussen vele ander. Terselfdertyd is die kerk die liggaam van Christus en mense is deel van sy 
Liggaam, van Christus self. Christus is ook die hoof van die Liggaam, die hoof van die kerk. Christus se verhouding met die kerk is tweeledig: Hy is die skepper van die bestaan van die kerk; die voortbestaan berus in Hom, die meesterbouer van die kerk; en $\mathrm{Hy}$ is ook terselfdertyd ten alle tye teenwoordig in die kerk, want die kerk is sy liggaam en Hy heers daaroor soos die hoof oor 'n liggaam heers. Die liggaam weer word deur die Heilige Gees beheers. Bonhoeffer tref onderskeid tussen die Heilige Gees en die Gees van Christus. Wat Christus vir die hele kerk is, is wat die Heilige Gees vir die individu is. Die Heilige Gees dryf die individu na Christus toe en bring ook Christus na die individu toe. Hy gee aan die mens gemeenskap met Christus (Bonhoeffer 1963:99).

Die aard van die kerk kan egter net van binne-af verstaan word en nooit van buite, vanuit 'n belangelose standpunt nie. Die enigste 'perspektief' wat ingespan kan word om die kerk te verstaan, is dié van die evangelie. Enige konsep van 'gemeenskap' hou met die konsep 'persoon' verband. Die vraag oor wat gemeenskap bepaal, kan slegs beantwoord word deur te vra wat 'n persoon bepaal. Omdat hierdie ondersoek oor 'n spesifieke soort gemeenskap gaan, sanctorum communio, moet 'n mens ondersoek hoe daardie soort gemeenskap 'persoon' verstaan. In wese beteken dit dat die Christelike konsep 'persoon' ondersoek moet word. Sodoende sal iets van waarde oor God gesê kan word. Die konsepte 'persoon', 'gemeenskap' en 'God' staan in 'n onoplosbare wederkerige verhouding tot mekaar. Dit is in verhoudings tussen persone en persoonlike gemeenskappe wat die Godskonsep gevorm word. In beginsel is die Christelike konsep oor gemeenskap vanuit sowel die Godskonsep as die persoonskonsep toeganklik. Bonhoeffer meen hy kies laasgenoemde benadering en daarom sal dit onmoontlik wees om oor gemeenskap te praat sonder om voortdurend na God te verwys.

'n Verstaan van die sonde is dus wesenlik vir 'n verstaan van sanctorum communio. Dieeerste mens het in liefdesgemeenskap geleef, maar die sondeval het dit na selfsugtigheid verander. Só het daar 'n skeiding gekom tussen die gemeenskap en God, sowel as tussen die gemeenskap en die mens. Dit het 'n verandering in die aard van die mens na vore gebring. Moraliteit en godsdiens in die ware sin van die woord het verlore gegaan en word nou slegs as wettiese vorme beskou. Elke mens leef nou in vrywillige isolasie deur die gebrokenheid van die gemeenskap. Elke mens leef nou 'n eie lewe in stede van dieselfde God-lewe. Elke mens het nou 'n eie gewete. Alle natuurlike vorme van gemeenskap bly bestaan, maar is deur die sondeval verdorwe. Die sonde raak nie net die persoon nie, maar dit raak die totale mens. Aan die een kant laat die sonde mens geheel en al eensaam agter, maar aan die ander kant dui die sonde op die wydste moontlike verbintenis wat tussen persoon en mensdom bestaan. Die sonde raak die individuele persoon sowel as die kollektiewe persoon, sowel as die totale mensdom (Bonhoeffer 1963:71).

Ná die sondeval het sowel gemeenskap as samelewing voortbestaan, nie meer in 'n vorm van suiwerheid nie, maar in relatiwiteit. Daar is nou geen gemeenskap sonder sonde nie, maar eweneens is ' $n$ samelewing nie net bloot 'n sondige gemeenskap nie (Bonhoeffer 1963):

Therefore $\sin$ in the community is not the newly-added individual will to self-preservation - which in fact makes community possible - but the sin is the will to affirm in principle oneself and not the other as a value, and to acknowledge the other only in relation to oneself. (bl. 81)

Die Christelike persoonskonsep is ' $n$ dus geheelbeskouing van die mens - konkrete persoon, liggaam en siel in verhouding tot ander persone spesifiek ten opsigte van morele relevansie. Elke persoon is uniek en anders as ander persone, maar kom eers in verhouding met God tot sy of haar volle reg. Dit bring 'n etiese dimensie na vore wat uniek is aan die Christelike persoonskonsep (Bonhoeffer 1963:35): 'Hence the individual belongs essentially and absolutely with the other, according to the will of God, even though, or even because, each is completelely seperate from the other'.

Beskou mens nou die kerk, nie in terme van hoe dit opgebou word nie, maar in terme van hoe dit as 'n eenheid in werklikheid bestaan, dan is dit die beeld van die liggaam van Christus wat dominant is. Christus is in die kerk aan die werk asof met ' $n$ instrument. Hy is teenwoordig daarin. Soos wat die Heilige Gees teenwoordig is by die individu, só is Christus teenwoordig in die gemeenskap van die heiliges (Bonhoeffer 1963:99). Neem mens die beeld van die liggaam ernstig op, dan beteken dit dat die kerk'n lewende organisme is. Dus, Christus is eers werklik teenwoordig in die kerk. Die kerk is in Hom soos wat Hy in die kerk is - en om in Christus te wees, is dieselfde as om in die kerk te wees (Bonhoeffer 1963:100).

\section{Menslikheid}

Die Christelike persoon is vir Bonhoeffer 'n persoon met 'n hart en met deernis, wat God se liefdeswil uitleef. Die medemenslike liefde word aan die Christelike persoon geopenbaar wanneer God as 'n Ek by die persoonlike ek ingang vind. Die virtuele kollektiewe persoon is gerig op menslikheid, weg van gesagstrukture en gefokus op die samevoeging van individuele bydraes tot 'n groter geheel.

Kohler (1970) wys daarop dat die persoon vir Bonhoeffer slegs in die verhouding tot goddelikheid verstaan kan word. Die persoon benodig die teenwoordigheid van andere. Persoonlikheid is altyd om ten opsigte van ander te wees, in verhouding met ander te wees en in konfrontasie met ander te wees. Die gemeenskap is ' $n$ web van verantwoordelike individue. Dit is slegs deur die God se selfopenbaring dat die mens weet wat goddelike liefde is. Bonhoeffer se persoonskonsep is gegrond in die inkarnasie van Christus waar God Hom tot die mens keer en intree in sy geskiedenis om die mens deur ' $n$ daad van plaasvervanging (substitution) tot sy ware wese te herskep (Kohler 1970:28).

Bonhoeffer toon aan dat Jesus deur sy eie mensheid die mensheid van die mens vernuwe. Die geskiedenis van Jesus 
en die geskiedenis van die mens word so met mekaar verweef. Jesus Christus se geskiedenis is egter slegs toeganklik deur die Woord - en daarom die van die mens ook. Slegs deur Christus en die Woord saam weet ons wat die verlede van die mens is en weet ons wat die toekoms van die mens inhou. Christus plaas Homself onder die wet. Hy toon egter aan dat die hele volk onder die wet afgedwaal het en sodoende deel is van die eerste Adam wat gered word. Die transformasie van die mensdom na 'n nuwe gemeenskap is slegs moontlik as mense van die tekortkominge van die oue bewus is. Daarom roep Jesus mense tot bekering - Hy openbaar God se opperste eis en maak die mense se verlede, hede en toekoms deel van die openbaring. So raak mense bewus van hulle skuld en van hulle geïsoleerde toestand. So word die ou gemeenskap onder die wet tot 'n gemeenskap in die openbaring van Christus vernuwe. Die wet bring nie gemeenskap nie, maar isolasie (deur die gebrokenheid van die mens). Die wet kan slegs vervul word deur die Gees - die volle integrering van God se wil in liefde (McBride 2012:126).

\section{'n Nuwe epistemologie vir die kerk ?}

Geloofsgemeenskap, gemeenskap van gelowiges - die sanctorum communio soos deur Bonhoeffer aangetoon ontsluit die waarde van onderlinge gemeenskap in die geloofsgemeenskap. Die gesag waarmee en waaronder gelowiges hulle wil aan God se wil onderhewig stel, is die Woord. Dit roep die gelowige tot verantwoordelikheid ten opsigte van die sanctorum communio. Dit is ' $n$ bevrydende behoort-aan en deelneem-aan 'n gemeenskap, want dit is om deel aan en in Christus te wees. Hierdie deelname word deur kollektiwiteit uitgedruk. Dit gaan oor die deelname aan die kollektiewe persoon van Christus. Soos wat kollektiwiteit in virtualiteit' $n$ nuwe epistemologie tot gevolg het, argumenteer hierdie studie dat kollektiwiteit ook aan die kerk 'n nuwe bevrydende epistemologie bied. Dit is 'n epistemologie wat postfoundationalist is en die voordeel van die transversal rationality wat daarmee gepaard gaan, ontgin - veral ten opsigte van die gesprek tussen die kerk en die wêreld en meer spesifiek tussen geloof en wetenskap.

Virtualiteit is dus 'n nuwe bril om na die kerk en die werklikheid te kyk, maar dit is nie net beperk tot ' $n$ bril nie. Dit is 'n nuwe lees om die teks van die kerk en die werklikheid mee te interpreteer, maar dit is nie net beperk tot lees nie. Dit is 'n nuwe koppelvlak om met die kerk en die werklikheid in interaksie te tree, maar dit is nie net interaksie nie. Dit is 'n sigbril, handskoen en 'n kopstuk; 'n immersiewe virtuele werklikheidservaring, om die kerk en die werklikheid sinvol mee te ervaar tot bevryding en herontdekking van die self en ander.

\section{Erkenning \\ Mededingende belange}

Die outeur verklaar hiermee dat hy geen finansiële of persoonlike verbintenis het met enige party wat hom nadelig of voordelig kon beïnvloed het in die skryf van hierdie artikel nie.

\section{Literatuurverwysings}

Aristoteles, 2009, Politics, transl. W.D. Ross, viewed 1 September 2015, from http:// classics.mit.edu/Aristotle/politics.html

Ballard, P.H., 1974, 'Bonhoeffer on providence in history', Scottish Journal of Theology 27(3), 268-286. http://dx.doi.org/10.1017/S0036930600058749

Bonhoeffer, D., 1963, The communion of saints: A dogmatic inquiry into the sociology of the church, transl. G.R. Smith, based on third German edition, Harper \& Row Publishers, New York.

Buitendag, J., 2013, 'Gaan na die mier, kyk na sy weë en word wys: Metafoor of paradigma?', HTS Teologiese Studies/Theological Studies 69(1), 1-9. http://dx.doi. org/10.4102/hts.v69i1.1976

Calvyn, J., 1845, Institutes of the Christian religion, transl. H. Beverage, viewed 23 September 2015, from http://www.ccel.org/ccel/calvin/institutes

Cui, X., 2004, A study of collective intelligence in multiagent systems, University of Louisville, Louisville, KY.

Davis, R., 1998, 'What are intelligence? And why?, 1998 AAAI presidential address', Al Magazine 19(1), 91-111.

De Jonge, M.P., 2012, Bonhoeffer's theological formation: Berlin, Barth, and protestant theology, Oxford University Press, Oxford.

De Lange, F., 1993, leder voor zich: Individualisering, ethiek en christelijk geloof, Kok, Kampen.

Green, C.J., 1999, Bonhoeffer: A theology of sociality, Eerdmans, Grand Rapids, MI.

Green, N., 1997, 'Beyond being digital: Representation and virtual corporeality', in D. Holmes (ed.), Virtual politics: Identity and community in cyberspace, pp. 59-78, Sage Publications, London.

Heim, M., 1993, The metaphysics of virtual reality, Oxford University Press, Oxford.

Holland, O.E. \& Melhuish, C., 1999, 'Stigmergy, self-organisation and sorting in collective robotics', Artificial Life 5(2), 173-202.

Kohler, R.F., 1970, 'The Christocentric ethics of Dietrich Bonhoeffer', Scottish Journal of Theology 23(1), 27-40. http://dx.doi.org/10.1017/\$0036930600021049

Lanier, J., 1988, A vintage virtual reality interview, viewed 3 August 2014, from http:// www.jaronlanier.com/vrint.html

Leibniz, G.W., 2007, The principles of philosophy known as monadology, transl. J. Bennet, viewed 1 September 2015, from http://www.earlymoderntexts.com/ assets/pdfs/leibniz1714b.pdf

Leibniz, G.W., [1710] 2009, Theodicy: Essays on the goodness of God, the freedom of man and the origin of evil, Cosimo, Inc., New York.

Lévy, P., 1999, Collective intelligence: Mankind's emerging world in cyberspace, Perseus Books, Cambridge.

Luther, M., 1529, Great Catechism, viewed 10 January 2016, from https://www. lutheransonline.com/lo/903/FSLO-1330564903-111903.pdf

Malone, T., 2008, 'What is collective intelligence and what will we do about it? Edited transcript of remarks at the official launch of the MIT Center for Collective Intelligence', in M. Tovey (ed.), Collective intelligence: Creating a prosperous world at peace, pp. 1-4, Earth Intelligence Network, Oakton, Virginia.

Marais, E.N., [1925] 2007, Die siel van die mier, reds. S.F. Honing, J.C. Kannemeyer, L. Klopper, M. Oosthuizen, M. \& L. Oosthuizen, Protea Boekhuis, Pretoria.

Marty, M., 1962, The place of Bonhoeffer: Essays on the problems and possibilities in his thought, Wipf and Stock, Eugene, Oregon.

McBride, J., 2012, The church for the world: A theology of public witness, Oxford University Press, Oxford.

Nunes, M., 1997, 'What space is cyberspace?: The internet and virtuality', in D. Holmes (ed.), Virtual politics: Identity and community in cyberspace, pp. 163-178, Sage Publications, London.

Reeves, J., 2013, 'Problems for postfoundationalists: Evaluating J. Wentzel van Huyssteen's interdisciplinary theory of rationality', Journal of Religion 93(2), 131-150. http://dx.doi.org/10.1086/669209

Roark, D.M., s.a., Dietrich Bonhoeffer, viewed 14 October 2014, from http://www. religion-online.org/showbook.asp?title $=2737$

Rodrígues, R.R., 2007, 'Liberating epistemology: Wikipedia and the social construction of knowledge', Religious Studies and Theology 26(2), 173-200.

Roux, B. \& De Beer, F., 2013, 'Onderweg na goeie wetenskap, 4: Evaluasie en kommunikasie', Litnet Akademies 10(2), 293-330.

Schlingensiepen, F., 2010, Dietrich Bonhoeffer 1906-1945: Martyr, thinker, man of resistance, A \& C Black, London.

Soltynski, M., 2006, The technological environment: Business futures. Instituut vir Navorsing, Bestuurskool, Universiteit van Stellenbosch, Belville.

Szuba, M.T., 2001, Computational collective intelligence, John Wiley \& Sons, New York.

Tovey, M., 2006, 'Mass collaboration, open source, and social entrepreneurship', in $\mathrm{M}$. Tovey (ed.), Collective intelligence: Creating a prosperous world at peace, $\mathrm{pp}$ 455-466, Earth Intelligence Network, Oakton.

Tyson, P.G., 2008, 'Transcendence and epistemology: Exploring truth via post-secular Christian Platonism', Modern Theology 24(2), 246-270. http://dx.doi. org/10.1111/j.1468-0025.2007.00444.x

Van Huyssteen, W.J., 1999, The shaping of rationality: Toward interdisciplinarity in theology and science, Eerdmans, Grand Rapids, MI.

Van Huyssteen, W.J., 2006, Alone in the world?: Human uniqueness in science and theology. The Giffiord Lectures 2004, Eerdmans, Grand Rapids, MI.

Zhai, P., 1998, Get real: A philosophical adventure in virtual reality, Rowman \& Littlefield Publishers. Lanham, MD. 